DOI:10.17951/h.2020.54.2.21-29

\begin{tabular}{lcc}
\hline \multicolumn{1}{c}{ A N N A L E S } \\
UNIVERSITATIS MARIAE CURIE-SKŁODOWSKA \\
LUBLIN - POLONIA \\
SOL. LIV, 2 & SECTIO H \\
\hline
\end{tabular}

\author{
JACEK JAKUBCZAK \\ jakubczak.jacek@gmail.com \\ Maria Curie-Skłodowska University. Faculty of Economics \\ 5 Maria Curie-Skłodowska Sq., 20-031 Lublin \\ ORCID ID: https://orcid.org/0000-0003-3517-197X
}

\title{
China's Foreign Investment Encouraged Catalogue and Negative Lists as a Tool of Foreign Direct Investment Attraction
}

Keywords: negative list; China; FDI

JEL: F21; K23; M16

How to quote this paper: Jakubczak, J. (2020). China's Foreign Investment Encouraged Catalogue and Negative Lists as a Tool of Foreign Direct Investment Attraction. Annales Universitatis Mariae Curie-Skłodowska, sectio H-Oeconomia, Vol. 54, No. 2.

\footnotetext{
Abstract

Theoretical background: Due to the growing maturity of Chinese market the country needs to adjust its policy regarding foreign direct investment (FDI), i.e. to increase openness for FDI, to keep control over them in key industries and to influence their inflow in desired industries and regions. Adopting the negative-list approach and changes in both the negative list and encouraged industry catalogue provides tools for this challenge.

Purpose of the article: The purpose of this article is to present how changes in China's Foreign Investment Encouraged Catalogue and Negative Lists both in free-trade zones (FTZs) and at the national level are used as a tool for managing country's FDI inflow.

Research methods: Analysis of legal documents and reports as well as literature review.

Main findings: Starting from the adoption of negative-list approach in FTZs in 2013, the negative lists had been drastically reduced both in reference to FTZs and national level. Those reductions lead to a decrease in China FDI restrictiveness index. FTZs were used as a testing area for both the negative list composition and negative-list approach itself. Negative lists allowed the state to keep control over FDI in key industries allowing, at the same time, greater freedom for foreign investors. Encouraged catalogue is used not only as a tool for attracting FDI from desired industries but also for addressing regional inequalities.
} 


\section{Introduction}

Since Deng Xiaoping opened China for foreign investors, the inflow of foreign direct investment (FDI) has drastically changed the country's economic landscape providing not only capital but also technology and know-how. The PRC, being the world's largest recipient of FDI for more than twenty years (Randau \& Medinskaya, 2016, pp. 16-17), witnessed astounding economic development. China's economic miracle is built on the investment-led growth model with the crucial role of both government and local government investments. In addition, FDIs were an important engine of this economic growth (accounting for around 6\% of GDP in 1993 and 1994, and between 3 to 5\% in the years 1995-2008). In time, the development of internal market and the rise in domestic consumption changed the perception of foreign investors - low-cost export model became less attractive mainly due to rising labour costs, but China started to change into the most important market. As the economy matures, the nature of FDI changed with observable acceleration of FDI inflow into the service sector instead of manufacturing sector. Despite continued economic growth it can be observed that since 2010, both the tempo of annual GDP growth and FDI inflow in regard to GDP has started to decrease. The Chinese government is aware of the limitations of investment-led model and in its development plan it set goals for more mature and sustainable economy and further increase in consumption. Nonetheless, the inflow of FDI is important for China's economy both in terms of providing short-term economic benefits and enabling China to take a leading role in specific high technology sectors. Reaching such goals would not be possible without proper policy tools. The PRC uses the specific instrument of negative lists and encouraged catalogue to affect the inflow of FDI by attracting those investments which are in line with its development plan and restricting or limiting those that may be dangerous to its home market. The purpose of the article is to present how the changes in FDI policy in recent years, regarding negative lists and encouraged catalogue, led to greater market openness and became a tool for attracting FDI.

\section{Literature review}

According to Zhang and Corrie (2018), China is currently during its fourth stage of opening for FDI. After a short period of no policy guidance (1979-1982), prioritizing the opening up of the secondary industry (1983-1990), and the experimental opening up of the tertiary industry (1991-2001), the new stage, in which China is already the WTO member, is described as a general opening up. To make this opening possible, regulations regarding FDI must allow foreign investors freedom of operation. In order to make that possible, it was necessary to implement pre-establishment national treatment (non-discriminative) and the negative-list approach regarding foreign investors (Zhang, 2019). In practice, adopting this approach means that foreign 
investors in non-restricted industries are allowed to operate and have at least the same legal rights as national investors. In line with this approach, foreign investment can be treated differently from domestic investment only if it falls into one of three categories, i.e. encouraged, restricted and prohibited. In case of encouraged list, a foreign investor operating in certain industries and areas can enjoy preferential treatment (e.g. tax reduction or lower land prices). Before investing in restricted industries, it is necessary to go through the process of obtaining administrative approval and meet additional requirements (e.g. regarding foreign and domestic capital composition). In case of prohibited industries, they are closed to foreign investment altogether. The reasons for including the industry on the restricted or prohibited list is a matter of broadly understood national security - including not only economic and financial aspects, but also those relating to cultural and societal security or public morality.

Until 2018, restricted and prohibited industries were included in guidelines for foreign investors as Part 2: Catalogue of Restricted Foreign Investment Industries, and Part 3: Catalogue of Prohibited Foreign Investment Industries (Part 1: Catalogue of Encouraged Foreign Investment Industries). First guidelines were published in 1995 under the name of Catalogue Guiding Foreign Investment. Since China entered the WTO in 2001, the Catalogue for the Guidance of Foreign Investment Industries was published in 2001 and then revised in 2004, 2007, 2011, 2015 and 2017. The national negative list was deleted from the Catalogue of Industries for Guiding Foreign Investment and presented under the name of the Special Administrative Measures on Access to Foreign Investment published in 2018 and revised in 2019. Also, in 2019, the Catalogue of Encouraged Foreign Investment Industries and the Catalogue of Advantageous Industries for Foreign Investment in Central and West China were derived from the 2017 Catalogue of Industries for Guiding Foreign Investment. This change means adopting a management mode, based on negative lists for investments (both national and foreign), as default one instead of mixed positive/ negative mode (Lewis \& Moise, 2018).

The concept of negative-list approach to foreign investment in China was first introduced in 2013 during the U.S.-China Strategic and Economic Dialogue on bilateral investment treaty and in the same year applied for FDI in Shanghai Free-Trade Zone, published as Special Management Measures (Negative List) for the Access of Foreign Investment in the China (Shanghai) Pilot Free Trade Zone. The same negative list was extended for Tianjin, Fujian and Guangzhou FTZ in 2015 (Marcus, 2016). Revisions to FTZ negative list were published as the Special Administrative Measures (Negative List) for Foreign Investment Access in Pilot Free Trade Zones in 2014, 2015, 2017, 2018 and 2019. It is important to observe that the role of those negative lists was to serve as a tool for making a substantial change in administering FDI and a way of opening China's market: reforming the logic of the system - from approval to filing - an important step towards decentralization and delegation of power (Zhao $\&$ OU, 2014). This approach, considering similar list composition (the 2013 Shanghai FTZ negative list was almost overlapping with the lists of restricted and prohibited 
industries from the 2011 Catalogue of Foreign-Funded Industries Guidance), is of a rather qualitative and not quantitative nature, affecting not only foreign investors but, to an even greater extent, modus operandi of Chinese administrative bodies. In this way the main purpose of FTZ is to serve as a testing ground for policies applied later in the scale of the country (Yao \& Whalley, 2016).

According to Markus (2016), the negative-list approach could limit government interference in FDI, however, the government's expanding perception on what qualifies as a national security issue and needs to be included in the restricted or prohibited list, as well as other restrictive Chinese laws and regulations are serious limitations to this process. From Chen's (2016) perspective, adaptation of the negative-list approach to FTZs was necessary due to international standards required for China's economic development. Referring to considerable success with regard to FTZs, Chen rises question whether this success can be replicated at the national level, especially in terms of state security.

\section{Research methods}

Adopted research methods were the analysis of legal documents and reports as well as literature review. Data used for research was taken from legal documents and reports (Catalogue for the Guidance of Foreign Investment Industries, The Special Administrative Measures [Negative List] on Access to Foreign Investment, The Free Trade Zone Special Administrative Measures on Access to Foreign Investment, The Catalogue of Encouraged Foreign Investment Industries and the Catalogue of Advantageous Industries for Foreign Investment in Central and West China, OECD FDI restrictiveness index). As Marcus (2016) observed, the length of China's negative lists itself can be used as an indicator of the country's interest in reducing government intervention in FDI. Apart from the analysis of the number of restricted, prohibited and encouraged industries enumerated on negative lists and encouraged catalogue, chain indexes were applied to present evolution of lists composition. Those changes were confronted with changes of FDI restrictiveness index defined by OECD: "gauging the restrictiveness of a country's foreign direct investment (FDI) rules by looking at four main types of restrictions: foreign equity restrictions; discriminatory screening or approval mechanisms; restrictions on key foreign personnel and operational restrictions" (OECD, 2019) to present changes both at the level of national economy and selected industries. This was followed by the analysis of the types of industries on the national prohibited list regarding the logic of the decision, in order to provide evidence to support the main hypothesis according to which changes in China's negative lists and encouraged catalogue are used as a tool for FDI attraction allowing their industrial and geographical composition. 


\section{Results}

Since the introduction of the negative-list approach in FTZs there have been made numerous amendments as far as the content of the lists of restricted and prohibited industries is concerned, and as a result they are getting shorter. The initial list for FTZs from 2013 included in fact 10 items more than the lists of restricted and prohibited industries in 2011 (Catalogue of Foreign-Funded Industries Guidance) which was in force at that time. The use of negative lists as a tool to increase government restrictions on foreign direct investment may raise concerns, but in reality it was a step towards greater openness, because the negative list management mode lifted other restrictions on foreign direct investment when it comes to treating them on an equal footing with national investments. Changes in lengths of negative lists both for general economy and FTZs are presented in Figure 1. Reductions of the number of restricted and prohibited industries for general economy and FTZs with each revision are shown in Table 1.

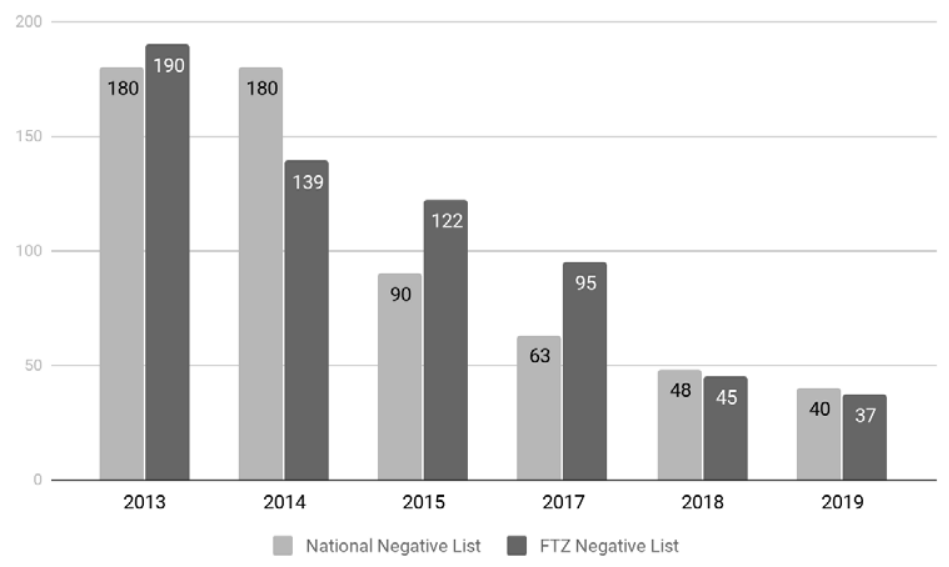

Figure 1. Number of restricted and prohibited items enumerated in China's national and FTZ negative lists Source: (Ye Zhang, 2019).

Table 1. Reduction of positions of restricted and prohibited industries in China's national and FTZ negative lists after 2013

\begin{tabular}{|l|c|c|c|c|c|}
\hline \multicolumn{1}{|c|}{ Year of publication } & 2014 & 2015 & 2017 & 2018 & 2019 \\
\hline National Negative List reduction by number of positions & - & 90 & 27 & 15 & 8 \\
\hline FTZ Negative List reduction by number of positions & 51 & 17 & 27 & 50 & 8 \\
\hline Relative National Negative List reduction & - & $50 \%$ & $30 \%$ & $24 \%$ & $17 \%$ \\
\hline Relative FTZ Negative List reduction & $27 \%$ & $12 \%$ & $22 \%$ & $53 \%$ & $18 \%$ \\
\hline
\end{tabular}


Overall, the number of restricted and prohibited industries at the national level for foreign FDI was reduced by 140 positions (78\%) in the years 2011-2019, and for FTZs - by 153 positions (81\%). During the whole period 2011-2019, each amendment to the negative lists brought a decrease in the number of restricted and prohibited industries ranging from 12 to $53 \%$.

The number of industries included in the catalogue of the encouraged industries for foreign investment (Catalogue of Encouraged Industries) was expanded. In 2015, there were 349 industries, whereas in 2019, there were 415 industries (increase by 19\%), with 348 industries included in the 2017 revision. As for the Encouraged Catalogue in the Central and Western Region, in 2013, there were 500 industries, whereas in 2019, there were as many as 639 industries (increase by 39\%), with 639 industries in the 2017 revision. As the Encouraged Catalogue in the Central and Western Region is $67 \%$ longer than the national encouraged industries list, it plays an important role as a tool for reducing regional disparities. As so far most FDI has been located in the eastern regions, attracting investors to less developed regions is crucial for the harmonious development of the country.

These changes were reflected in the OECD FDI restrictiveness index which in the years $2011-2018$, fell by $41.22 \%$ from 0.426 to 0.251 , still staying much higher than OECD average of 0.065 . Changes in OECD FDI restrictiveness index are presented in Figure 2.

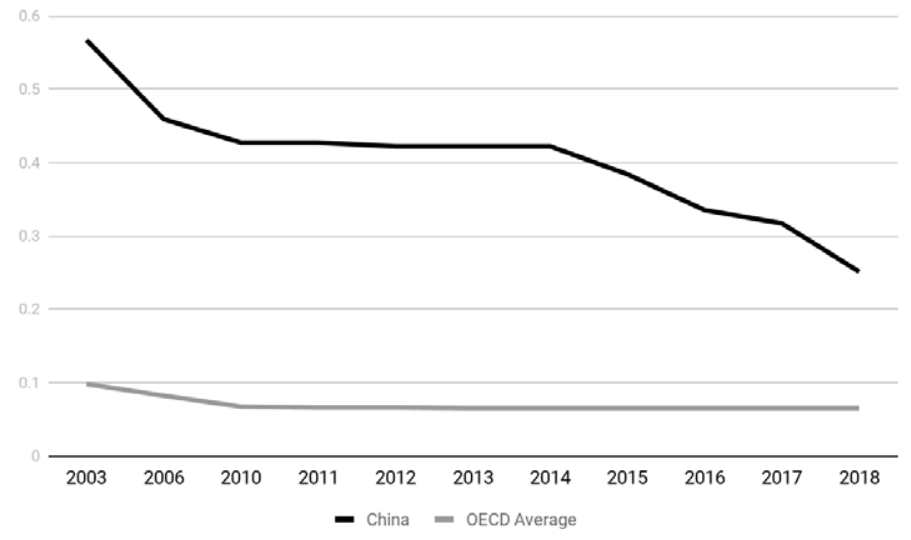

Figure 2. OECD FDI restrictiveness index for China and OECD countries average for the years 2003-2018 Source: (OECD, 2019).

In the years 2011-2018, for individual industries, the OECD restrictiveness index fell in 32 out of 39 classified industries, remained at the same level for 5 industries and increased only for 2 . Table 2 presents the most and the least restricted industries for FDI access in 2018, while Table 3 presents the level of restrictiveness for particular industries. 
Pobrane z czasopisma Annales H - Oeconomia http://oeconomia.annales.umcs.pl Data: 26/04/2023 09:16:40

CHINA'S FOREIGN INVESTMENT ENCOURAGED CATALOGUE AND NEGATIVE LISTS...

Table 2. Top 5 most and least restricted industries in China for FDI in 2018

\begin{tabular}{|l|c|l|c|}
\hline \multicolumn{1}{|c|}{$\begin{array}{c}\text { Most restricted } \\
\text { industries }\end{array}$} & $\begin{array}{c}\text { Restrictiveness } \\
\text { index value }\end{array}$ & $\begin{array}{c}\text { Least restricted } \\
\text { industries }\end{array}$ & $\begin{array}{c}\text { Restrictiveness } \\
\text { index value }\end{array}$ \\
\hline Fisheries & 1 & Forestry & 0.05 \\
\hline Media & 0.985 & Food manufacturing & 0.05 \\
\hline Communications & 0.75 & Electricity distribution & 0.05 \\
\hline Legal services & 0.75 & Surface transport & 0.05 \\
\hline Air transport & 0.75 & Banking & 0.05 \\
\hline
\end{tabular}

Source: (OECD, 2019).

Table 3. Top 5 industries with largest change in restrictiveness in the years 2011-2018

\begin{tabular}{|l|c|l|c|}
\hline \multicolumn{1}{|c|}{$\begin{array}{c}\text { Least open } \\
\text { industries }\end{array}$} & $\begin{array}{c}\text { Decrease in the } \\
\text { restrictiveness index value }\end{array}$ & \multicolumn{1}{|c|}{$\begin{array}{c}\text { Most open } \\
\text { industries }\end{array}$} & $\begin{array}{c}\text { Decrease in the } \\
\text { restrictiveness index value }\end{array}$ \\
\hline Legal services & -0.1 & Electricity distribution & 0.7 \\
\hline Air transport & -0.07 & Banking & 0.45 \\
\hline Fisheries & 0 & Maritime transport & 0.375 \\
\hline Communications & 0 & Surface transport & 0.35 \\
\hline Media & 0.015 & Accounting \& audit & 0.35 \\
\hline
\end{tabular}

Source: (OECD, 2019).

As can be seen, 4 out of 5 most restrictive industries for FDI are also the ones with the lowest level of reduction of restrictiveness in recent years. Similarly, 2 out of 5 least restrictive industries are the ones with the highest level of reduction of restrictiveness. Due to the specific link of restricted and prohibited industries, their restrictiveness remains limited to industries raise national security concerns. Out of 23 prohibited industries on the 2019 national Negative List, the probable prohibition reasons can be grouped into the following:

- social security -11 industries (related to media, news agencies, social research and organizations, education, performing arts groups and book publishing),

- military and economic security -5 industries (related to rare earths elements and radioactive minerals, production of nuclear fuel; geology research and air traffic control),

- protection of culture and heritage - 3 industries (related to rare and unique Chinese varieties, traditional Chinese medicine, cultural relics and heritage),

- health and ecological security - 2 industries (related to tobacco products, aquatic products, and GMO),

- other -1 industry (stem cells research).

\section{Discussion}

Concerns regarding the increasing complexity of negative lists or the ones connected with the expanding definition of "national security" (Marcus, 2016) have not been confirmed by government actions yet. In fact, there is a tendency to shorten 
the negative lists on the nearly yearly basis which provides more and more freedom for operation for foreign investors both in FTZs area and at a national level. What is more, it is in line with the observations of Yao \& Whalley (2016) who claim that FTZs are testing areas for regulations that, if successful, would be later applied at the national level. Concerns about the government's loss of control over FDI were also not confirmed. Zhao \& OU (2014) pointed out the difficulty of including on the negative lists emerging, "future" industries that may be of extreme importance for economy or state security, although, taking into consideration the regular changes in the composition of negative list, the potential inclusion of such industries should not be problematic.

\section{Conclusions}

Chinese government is actively using tools such as China's Foreign Investment Encouraged Catalogue and Negative Lists to attract FDI. What is more, FTZs are used as a testing ground for new policies that later could be applied for the whole country. The negative-list approach provides the sufficient level of government control over FDI and national security by prohibiting and restricting access to key sectors while leaving a high level of freedom for FDI. Revisions of Negative Lists to date resulted in their reduction and alleviating legal restrictions for FDI. Encouraged catalogue is a tool which is used not only for shaping preferred industrial composition by encouraging FDI inflow in desired industries, but also for addressing geographical inequalities by investing in less developed regions. Due to the limitations of the study, it was not possible to examine the impact of changes in FDI management mode on negative lists, reduction in the composition of negative lists and expansion of encouraged catalogue. It may be an area for future research to test how changes implemented in the encouraged catalogue and negative lists in different industries affected the composition of FDI inflow both in terms of industry and geographical location of investment. It may also be interesting to compare policy changes with the inflow of FDI to industries and regions to assess it as a tool for reducing regional disparities.

\section{References}

Chen, C. (2016, January). The Negative List in China - Causation, Content and Implication. In International Conference on Humanities and Social Science 2016. Atlantis Press. doi:10.2991/hss-26.2016.89

Lewis, D.J., \& Moise, D. (2018). One Belt One Road (“OBOR”) Roadmaps: The Legal and Policy Frameworks. In J. Chaisse, J. Górski (eds.), The Belt and Road Initiative (pp. 17-58). Boston: Brill Nijhoff. doi:10.1163/9789004373792_003

Marcus, D. (2016). China and the Negative-List Principle: Possibilities and Uncertainties. In S. Kennedy (Ed.), State and Market in Contemporary China: Toward the $13^{\text {th }}$ Five-Year Plan (pp. 36-39). Lanham-Boulder-New York-London: Rowman \& Littlefield. 
Pobrane z czasopisma Annales $\mathrm{H}$ - Oeconomia http://oeconomia.annales.umcs.pl

Data: 26/04/2023 09:16:40

CHINA'S FOREIGN INVESTMENT ENCOURAGED CATALOGUE AND NEGATIVE LISTS...

OECD. (2019). FDI restrictiveness (indicator). doi:10.1787/c176b7fa-en

Randau, H.R., \& Medinskaya, O. (2016). China Business 2.0. New York-London: Springer. doi:10.1007/9783-319-07677-5

Yao, D., \& Whalley, J. (2016). The China (Shanghai) pilot free trade zone: Background, developments and preliminary assessment of initial impacts. The World Economy, 39(1), 2-15. doi:10.1111/twec.12364

Ye Zhang, Z. (2019, July 19). China's Negative Lists, Encouraged Catalogue for Foreign Investment. Retrieved from https:/www.china-briefing.com/news/chinas-2019-negative-lists-encouraged-catalogue-foreign-investment

Zhao, Z., \& OU, S.Y. (2014). The thinking of "negative list" management mode implemented by administrative approval system. Canadian Social Science, 10(4), 120-124. Retrieved from http://www. cscanada.net/index.php/css/article/view/4714, doi:10.3968/4714

Zhang, L. (2019, May 30). China: Foreign Investment Law Passed. [online] Law Library of Congress. Retrieved from https://www.loc.gov/law/foreign-news/article/china-foreign-investment-law-passed/

Zhang, X., \& Corrie, B.P. (2018). Chinese policies on encouraging foreign investment. In Investing in China and Chinese Investment Abroad (pp. 13-20). Singapore: Springer. doi:10.1007/978-981-10-7983-2_11 